\title{
Molecular cloning and characterization of tiger shrimp (Penaeus monodon) transglutaminase
}

\author{
Chih-Cheng Huang $^{a}$, Kallaya Sritunyalucksana ${ }^{b}$, Kenneth Söderhäll ${ }^{c}$, \\ Yen-Ling Song ${ }^{\mathrm{a}, \mathrm{d}, *}$ \\ ${ }^{a}$ Institute of Zoology, National Taiwan University, Taipei 106, Taiwan, ROC \\ ${ }^{\mathrm{b}}$ Center of Excellence in Shrimp Molecular Biology and Biotechnology, Faculty of Science, Mahidol University, Bangkok 10250, Thailand \\ ${ }^{\mathrm{c}}$ Department of Comparative Physiology, Evolutionary Biology Centre, Uppsala University, Sweden \\ ${ }^{\mathrm{d}}$ Department of Life Science, National Taiwan University, Taipei 106, Taiwan, ROC
}

Received 16 March 2003; revised 20 August 2003; accepted 27 August 2003

\begin{abstract}
Transglutaminases (TG) are important for blood coagulation and post-translation remodeling of proteins. Using a plaque screening assay, we isolated cDNA encoding a novel TG from a shrimp (Penaeus monodon) hemocyte cDNA library. The TG cDNA consists of $2988 \mathrm{bp}$ with an open reading frame of $2271 \mathrm{bp}$. The deduced protein has 757 amino acid residues, a calculated molecular mass of 84,713 Da and an isoelectric point of 5.56. Neither a typical hydrophobic leader sequence nor a transmembrane domain could be identified from the deduced sequence. Thus, shrimp TG may be a typical cytoplasmic protein. The sequence of shrimp TG was similar to crayfish, other invertebrate and vertebrate TG sequences. Enzyme activity was detected in all organs tested. This is consistent with the widespread, low-level expression of TG mRNA. However, high levels of TG expression were detected in hematopoietic tissue. TG signals were stronger in mitotic cells, indicating that cell proliferation and TG synthesis are associated. Preliminary data showed that recombinant TG existed the enzyme activity but lacked coagulation activity.

(C) 2003 Elsevier Ltd. All rights reserved.

Keywords: Transglutaminase; Coagulation; Penaeus monodon; Shrimp; In situ hybridization; Hematopoietic tissue; Hemocyte; Cell proliferation

\section{Introduction}

Transglutaminases (TG) (EC 2.3.2.13) are known primarily for their roles in blood coagulation and posttranslational protein remodeling. Enzymes in this

\footnotetext{
* Corresponding author. Tel.: +886-223-630-231x3355; fax: +886-223-660-243.

E-mail address: song@ccms.ntu.edu.tw (Y.-L. Song).
}

family use a modified double-displacement mechanism to execute a calcium-dependent acyl transfer reaction between the $\gamma$-carboxamide group of a peptide-bound glutamine residue and the $\varepsilon$-amino group of a peptide-bound lysine or the primary amino group of a polyamine. When a protein-bound lysine residue acts as an acyl acceptor, intermolecular or intramolecular $\varepsilon$ - $(\gamma$-glutamyl) lysine bonds form, resulting in protein polymerization $[1-4]$.
\end{abstract}


In vertebrates, eight different TG gene products have been characterized based on primary structure [5]. In addition to this gene level diversity, TG undergo a number of post-translational modifications, including phosphorylation, fatty acylation, and proteolytic cleavage, that regulate their enzymatic activity and subcellular localization [6-10]. TG are widely distributed in tissues and body fluids, and specialize in cross-linking particular proteins or tissue structures for a variety of biological processes. Blood coagulation factor XIIIa catalyzes the cross-linking of fibrin monomer during blood coagulation [11]. Both TG1 (a membrane-bound form of $\mathrm{TG}_{\mathrm{K}}$ in keratinocytes) and TG3 $\left(\mathrm{TG}_{\mathrm{E}}\right.$ occurring as a proenzyme in the epidermis) help maintain toughened skin epidermis and hair follicle epithelia by cross-linking structural proteins [12-16]. TG2 (tissue $\mathrm{TG} / \mathrm{TG}_{\mathrm{C}}$ distributed mainly in the cytosol of many cells and tissues) has been implicated in apoptosis, and the formation and stabilization of the extracellular matrix. In certain signal transduction pathways, TG2 acts as the GTPbinding protein, $\mathrm{G}_{\mathrm{h}}$. It profoundly affects cells by regulating the biological activity of signaling molecules, including transforming growth factor- $\beta$, interleukin-2 and midkine, and by modulating cellmatrix interactions [17-21]. TG4 $\left(\mathrm{TG}_{\mathrm{P}}\right.$ found in the prostate) is essential for semen coagulation [22]. Human TG X, Y and Z have been discovered recently and their function is still unknown $[5,10]$.

In invertebrates, only one TG gene product has been identified from each species. In vertebrates and invertebrates, blood clotting reduces the blood loss following injury. A novel TG gene, whose sequence is homologous with that of factor XIIIa, was isolated from crayfish (Pacifastacus leniusculus) [23]. Crayfish TG plays a role in blood clotting. The presence of endogenous TG causes rapid assembly of a specific plasma clotting protein [24]. In contrast, the TG cloned from horseshoe crab (Limulus polyphemus) hemocytes does not recognize coagulogen or coagulin as the substrate [25,26]. However, horseshoe crabs use the TG cross-linking reaction during the final stage of coagulation [27]. Annulin is homologous to the TG expressed at limb segment boundaries in grasshopper (Schistocerca americana) embryos. The pattern of annulin expression within the limb and the embryo is associated with areas undergoing morphogenetic rearrangements, movements, or rapid cell division. It may stabilize cells under mechanical stress or participate in morphogenesis in some other way [28]. A novel TG (nuclear TG, nTG) that occurs exclusively in the nucleus of embryonic starfish (Asterina pectinifra) cells was described recently [29]. Because nTG mRNA first appears during the early blastula stage and increases thereafter, this enzyme may be important for nuclear remodeling during early starfish embryogenesis. A TG homologue from the Drosophila genome, gene product CG7356, has been identified [30]. Its function is still unknown.

In this study, we isolated from tiger shrimp (Penaeus monodon) a cDNA that encodes a novel TG. Based on the preservation of residues critical for enzyme function and domain folding, and the extensive, overall similarity of shrimp TG to the other members of the TG family with catalytic activity, we postulate that the characterized cDNA encodes an active TG. The specific function of shrimp TG was not identified in this study. However, we found high levels of TG expression in different tissues. Thus, shrimp TG may be involved in other biological processes.

\section{Materials and methods}

\subsection{Construction of a cDNA library and screening for transglutaminase}

Live shrimp ( $P$. monodon) were purchased from the local market. Shrimp hemolymph was collected using an anticoagulant, shrimp salt solution (SSS) [31], and centrifuged for $5 \mathrm{~min}$ at $500 \mathrm{~g}$ and $4{ }^{\circ} \mathrm{C}$. The hemocyte pellet was re-suspended in Trizol (Gibco BRL). The total RNA was extracted and further purified using an mRNA isolation kit (Pharmacia). An oligo-dT primed cDNA library was constructed using a UNI-ZAP XR cDNA synthesis kit (Stratagene). The cDNA was inserted into the Eco RI-Xho I site of $\lambda$ phages and subjected to in vivo packaging, as described in the manufacturer's instructions.

A 392 bp-fragment, which was derived from crayfish TG (AAK69025) and contained His and Asp of the catalytic triad, was ${ }^{32} \mathrm{P}$-labelled using the Megaprime $^{\mathrm{TM}}$ DNA labeling system (Amersham). The labeled fragments were separated from unincorporated ${ }^{32} \mathrm{P}$-labelled nucleotides $\left(\mathrm{NICK}^{\mathrm{TM}}\right.$ column, 
Pharmacia Biotech) and then used for the initial screening of 5,00,000 plaques from the hemocyte cDNA library. Hybridizations were carried out overnight at $63{ }^{\circ} \mathrm{C}$ in a hybridization buffer containing $5 \times$ Denhardt's solution, $5 \times \mathrm{SSC}(0.75 \mathrm{M} \mathrm{NaCl}$, $0.075 \mathrm{M}$ Na-citrate, $\mathrm{pH} 7.0), 0.5 \% \mathrm{SDS}$ and $1 \mathrm{mg} / \mathrm{ml}$ salmon sperm DNA. Membranes were washed at $63{ }^{\circ} \mathrm{C}$ with $2 \times \mathrm{SSC}$ containing $0.1 \%$ SDS and autoradiographed. Secondary screening was performed to purify positive plaques. Phagemids, obtained by in vivo excision using EXASSIST Helper phage with SOLR strain (Stratagene), were used for sequencing.

\subsection{Rapid amplification of $5^{\prime}-m R N A$ ends}

The total RNA in shrimp hemocytes was isolated using Trizol reagent (Gibco, BRL) according to manufacturer's instructions. To synthesize cDNA by reverse transcription, $4 \mu \mathrm{g}$ total RNA, THERMOSCRIPT $^{\mathrm{TM}}$ reverse transcriptase and $0.5 \mu \mathrm{M}$ oligo $(\mathrm{dT})_{20}$ or $5^{\prime}$-TTCTTGAATCCTCCCTCCGC- $3^{\prime}$ (reverse, STG3) primer were reacted for $1 \mathrm{~h}$ at $50{ }^{\circ} \mathrm{C}$ in $20 \mu \mathrm{l}$ reaction mixture containing $1 \mathrm{mM} \mathrm{dNTP}$ and $5 \mathrm{mM}$ dithiothreitol in first strand buffer. The cDNA was purified using a GlassMax DNA isolation kit (Life Technologies, Inc.). To anchor the PCR product at the $5^{\prime}$ end, cDNA was tailed for $10 \mathrm{~min}$ at $37^{\circ} \mathrm{C}$ using 15 units of terminal deoxynucleotidyl transferase (Promega) and $200 \mu \mathrm{M}$ dCTP. To amplify the $5^{\prime}$-mRNA ends of shrimp TG, we used a series of TGspecific primers as follows: 5'-CCAGATGGAGT CACGAATG-3' (reverse, STG2) and 5'-GGCCACG CGTCGACTAGTACGGGIIGGGIIGGGIIG-3' (forward, anchor primer, AP), with nested reactions 5'-TGGAGAGTGAGATGTTGGTG-3' (reverse, STG5) and 5'-GGCCACGCGTCGACTAGTAC-3' (forward, abridged universal amplification primer, AUAP); 5'-CGAACACCCAGCACTGGCCG-3' (reverse, STG6) and AP, with nested reactions $5^{\prime}-\mathrm{G}$ TCCCCGCGCGCCTCGGC-3' (reverse, STG7) and AUAP. PCR was performed using $1 \mu \mathrm{l}$ reverse transcription reaction mixture, 2.5 units VioTaq DNA polymerase (Viogene) and the respective buffer supplemented with $1.5 \mathrm{mM} \mathrm{MgCl}_{2}, 0.2 \mathrm{mM} \mathrm{dNTP}$ and $0.2 \mu \mathrm{M}$ of each primer, in a total volume of $50 \mu \mathrm{l}$. A robocycler ran 25 cycles. Except for the first and last cycles, each cycle included denaturation at $94{ }^{\circ} \mathrm{C}$ for $1 \mathrm{~min}$, annealing at $55^{\circ} \mathrm{C}$ for $1 \mathrm{~min}$, and extension at $72{ }^{\circ} \mathrm{C}$ for $1.5 \mathrm{~min}$. The first cycle included an extended ( $2 \mathrm{~min}$ ) denaturation period during which polymerase was added (hot start) and the last cycle had an extended (10 min) elongation period. The first round of PCR was carried out with AP and TG -specific primer under the conditions described above. Nested PCR was performed with the AUAP and TG -specific primer using $1 \mu \mathrm{l}$ of the first round PCR product. Amplified products were analyzed on $1.5 \%$ agarose gel, extracted with a Gel-M ${ }^{\mathrm{TM}}$ gel extraction kit (Viogene) and sequenced.

\subsection{RT-PCR analysis of TG from different tissues}

Total RNA was extracted from a variety of shrimp tissues, including the eyestalk, intestine, hepatopancreas, gill, heart, lymphoid organ, sub-cuticular epithelium and hemocyte. An 806-bp fragment of shrimp TG was amplified by PCR using oligonucleotides $5^{\prime}$ AGGGTTCTTCAAGTCGGAC-3' (forward) and 5'-CAGTTCGTCTCCAGATTCAAG-3' (reverse). RT-PCR was performed as described above. The PCR products were sequenced to ensure that they corresponded to the expected cDNA sequence.

\subsection{In situ hybridization of TG $m R N A$ in tissue sections}

\subsubsection{Tissue preparation for histology}

Juvenile shrimp were fixed in a RNA-friendly fixative containing $34.9 \%$ formalin, $40.7 \%$ ethanol and $2.2 \%$ ammonium hydroxide $(\mathrm{pH} 6.5)$ [32]. After dehydration, samples were embedded in Paraplast and $4 \mu \mathrm{m}$ sections were cut, mounted on slides and stored at $4{ }^{\circ} \mathrm{C}$ until used.

\subsubsection{Riboprobe preparation}

A plasmid pGEM-T Easy (Promega) containing a 350-nucleotide region (1535-1884nt) of shrimp TG cDNA was used as the template for the preparation of probes. This region contained a sequence encoding the barrel 1 domain. Digoxigenin (DIG)-UTP-labeled sense and antisense riboprobes were generated from linearized cDNA plasmids $(5 \mu \mathrm{g})$ by in vitro transcription RNA labeling kits T7 and SP6 RNA polymerase (Boehringer, Mannheim), respectively. 


\subsubsection{In situ hybridisation}

Tissue sections were deparaffinized in xylene and hydrated through a graded ethanol series. After proteinase $\mathrm{K}$ digestion $\left(20 \mu \mathrm{g} / \mathrm{ml}, 30 \mathrm{~min}\right.$ at $\left.37^{\circ} \mathrm{C}\right)$, the sections were acetylated for $10 \mathrm{~min}$ at room temperature $(0.25 \%$ acetic acid, $0.1 \mathrm{M}$ triethanolamine, $\mathrm{pH}$ 8.0), dehydrated in ethanol and air-dried. Sections were incubated at $42^{\circ} \mathrm{C}$ in a hybridization buffer of $1 \times \mathrm{SSC}, 50 \%$ formamide (Amresco), $1 \times$ Denhardt's solution, $5 \%$ dextran sulfate (Sigma), $1 \mathrm{mg} / \mathrm{ml}$ yeast tRNA (Sigma), and $10 \mathrm{ng} /$ slide of probe. After hybridization, the sections were washed in $1 \times \mathrm{SSC}$ for $30 \mathrm{~min}$ and in $0.1 \times \mathrm{SSC}$ for $15 \mathrm{~min}$ at $50{ }^{\circ} \mathrm{C}$. Then the sections were digested with $20 \mu \mathrm{g} / \mathrm{ml}$ RNase (Sigma) for $30 \mathrm{~min}$. Hybridization signals were detected with an enzyme-linked immunoassay as described in the manufacturer's manual (Nucleic Acid Detection Kit: Boehinger, Germany). The enzyme reaction was stopped with $100 \%$ methanol for $10 \mathrm{~min}$. Sections were counterstained with Bismarck Brown Y (Sigma), dehydrated and made transparent with a graded ethanol and xylene series, and then mounted in GEL/MOUNT ${ }^{\mathrm{TM}}$ (Biømeda corp).

\subsection{TG activity in different tissues}

\subsubsection{Preparation of sample}

Hemolymph was collected into an anticoagulant (10 mM Tris- $\mathrm{HCl}, 250 \mathrm{mM}$ sucrose, $100 \mathrm{mM}$ sodium citrate, $\mathrm{pH} 7.6$ ) and centrifuged for $10 \mathrm{~min}$ at $500 \mathrm{~g}$ and $4{ }^{\circ} \mathrm{C}$ to separate the hemocytes and plasma. Shrimp tissues, including the eyestalk, intestine, hepatopancreas, gill, heart, lymphoid organ and sub-cuticular epithelium, were manually homogenized. Liquid nitrogen was added continually to maintain a sufficiently low temperature. The hemocyte pellet and tissue homogenate were re-suspended in a TrisEDTA buffer (50 mM Tris- $\mathrm{HCl}$ and $1 \mathrm{mM}$ EDTA, $\mathrm{pH}$ 7.4), centrifuged to eliminate debris, and stored at $-20^{\circ} \mathrm{C}$. Plasma was mixed with Tris-EDTA buffer and stored at $-20^{\circ} \mathrm{C}$. Standard enzyme, a tissue-type TG from guinea pig liver (Sigma), was dissolved in Tris-EDTA buffer to an initial activity of $0.25 \mathrm{U} / \mathrm{mg}$.

\subsubsection{Assay procedure}

TG activity was assayed as described by Song et al. [33]. Casein $(200 \mu \mathrm{g} / \mathrm{well})$, coated on the microtitre plates overnight, and biotin-labeled casein $(0.8 \mu \mathrm{g} /$ well) were used as substrates in a TG-dependent cross-linking reaction. For the assay, each sample was serially diluted two-fold with $50 \mathrm{mM}$ Tris $-\mathrm{HCl}$, $1 \mathrm{mM}$ EDTA, pH 7.4, and supplemented with $\mathrm{CaCl}_{2}$ or EDTA to achieve a final concentration of $10 \mathrm{mM}$ in each well. Streptavidin-labeled alkaline phosphatase (Calbiochem), followed by $p$-nitrophenyl phosphate, were added to visualize immobilized biotin. Absorbance at $405 \mathrm{~nm}$ was measured. Using guinea pig liver TGase, a standard curve was established for enzyme activity (unit/mg) and OD $405 \mathrm{~nm}$. The protein concentration in each sample was determined by the Bradford method [34] using bovine serum albumin (Bio-Rad Protein assay Kit II) as the standard.

\subsection{Analysis of nucleotide and amino acid sequences}

The nucleotide and deduced amino acid sequences of shrimp TG cDNA were analyzed using a GCG (Genetic Computer Group, Inc., Madison, Wisconsin) software package. The sequences of different species were compared with the NCBI BLAST search program and NCBI Blast search with Entrez. The amino acid sequences of all cloned TG were aligned with the DAMBE (Data Analysis in Molecular Biology and Evolution, version 4.0.75) software package [35]. A multiple sequence alignment was created with Clustal W. Phylogenetic and evolutionary molecular analyses were conducted using MEGA version 2.1 [36]. The phylogenetic tree was constructed using the neighbor-joining method [37].

\subsection{Expression of recombinant $T G(r T G)$}

The StuI-BglII fragment, which contained the entire coding region of shrimp TG, was inserted between the StuI and $B g l \mathrm{II}$ sites of baculovirus transfer vector $\mathrm{pABhRpX}$ to obtain a pABhRpXTG transfer plasmid. Sf21 insect cells were grown at $26^{\circ} \mathrm{C}$ in TNM-FH insect medium (GIBCO) containing $8 \%$ heat-inactived fetal bovine serum (HyClone) in a monolayer flask. The pABhRpX-TG plasmid was transfected with a BaculoGold linearized Baculovirus DNA (BD) into Sf21 cells with Lipofectin (GIBCO). After plaque purification, a single clone of each recombinant virus was amplified and used for protein expression. 
Harvested cells was re-suspended in Tris-EDTA buffer $(50 \mathrm{mM}$ Tris- $\mathrm{HCl}$ and $1 \mathrm{mM}$ EDTA, $\mathrm{pH}$ $7.4)$, sonicated, centrifuged to eliminate debris and stored at $-20{ }^{\circ} \mathrm{C}$ until used in the TG activity and coagulation assay.

\subsection{Coagulation assay}

\subsubsection{Preparation of sample}

Hemolymph was collected into an anticoagulant (10 mM Tris- $\mathrm{HCl}, 250 \mathrm{mM}$ sucrose, $100 \mathrm{mM}$ sodium citrate, $\mathrm{pH}$ 7.6) and centrifuged for $10 \mathrm{~min}$ at $500 \mathrm{~g}$ and $4{ }^{\circ} \mathrm{C}$ to separate the hemocytes and plasma. Plasma was dialyzed against Tris-EDTA buffer and stored at $-20^{\circ} \mathrm{C}$. The relative activity of TG was adjusted so it was the same in sample solutions from shrimp tissues and Sf21 cells transfected with rTG. The sample solutions then were used in coagulation assays.

\subsubsection{Assay procedure}

To assess the role of shrimp TG in coagulation, $100 \mu \mathrm{l}$ plasma, $10 \mu \mathrm{l} 200 \mu \mathrm{M} \mathrm{CaCl}_{2}$ solution and $50 \mu \mathrm{l}$ of each sample solution were added to a roundbottom 96-well microdilution plate (Nunc. Denmark). The solutions were mixed thoroughly and incubated at room temperature. Coagulation was evaluated by eye.

\section{Results}

\subsection{Localization of TG activity}

Tissue homogenate was extracted from several shrimp organs to determine the distribution of TG protein. TG activity was detected in the eyestalk, intestine, hepatopancreas, gill, heart, lymphoid organ, sub-cuticular epithelium and hemocytes, but no activity was detected in the plasma. In all organs tested, TG activity was blocked when $10 \mathrm{mM}$ EDTA was added instead of $10 \mathrm{mM} \mathrm{CaCl} 2$. TG activity was greatest in the hepatopancreas, then the heart, hemocytes and other organs (Table 1). TG activity was detected in Sf21 cells transfected with rTG. No activity was detected in Sf21 cells not transfected with rTG.
Table 1

TG activity in the hemocytes, other tissues of Penaeus monodon and TG transfected cells

\begin{tabular}{ll}
\hline Tissue/cells $^{\mathrm{a}}$ & TG activity (Unit/mg) \\
\hline Hepatopancreas & 27.920 \\
Heart & 1.589 \\
Hemocyte & 1.111 \\
Lymphoid organ & 0.575 \\
Intestine & 0.322 \\
Sub-cuticular epithelium & 0.224 \\
Eyestalk & 0.118 \\
Gill & 0.042 \\
Plasma & Undetectable \\
Sf21 & Undetectable \\
TG transfected Sf21 & 0.195 \\
\hline
\end{tabular}

a All the tissues or cells were prepared in sample buffer containing $50 \mathrm{mM}$ Tris- $\mathrm{HCl}$ and $1 \mathrm{mM}$ EDTA, pH7.4.

b There was no detectable activity in the negative control, which was supplemented with $10 \mathrm{mM}$ EDTA instead of $10 \mathrm{mM} \mathrm{CaCl}_{2}$.

\subsection{Determination of the cDNA and amino acid sequences of shrimp TG}

Shrimp TG cDNA is comprised of $2988 \mathrm{bp}$, with an open reading frame of $2271 \mathrm{bp}$ (Fig. 1). The probable initiation codon is in the sequence CAAAATGC. It exhibits limited homology with the consensus sequence identified by Kozak [38] that acts as a signal for efficient transcription in eukaryotes. However, the critical purine in position -3 is conserved. The polyadenylation signal (AATAAA) was located 626 bp downstream of the termination codon (TGA). The deduced protein is comprised of 757 amino acid residues, has a calculated molecular mass of 84,713 $\mathrm{Da}$ and an isoelectric point of 5.56. It does not contain a typical signal sequence or a transmembrane domain. Four potential N-glycosylation sites and an integrin-binding motif (RGD) were identified (Fig. 1).

\subsection{Sequence comparison of shrimp TGase with other $T G$}

Shrimp TG had the highest identity/similarity $(55 / 71 \%)$ to crayfish TG (Fig. 2). Shrimp TG exhibited significant identity/similarity with other invertebrate $\mathrm{TG}$ and members of the vertebrate $\mathrm{TG}$ gene family, especially human factor XIIIa (32/50\%). Detailed comparison of the sequences by individual 
1

101

201

301

401

501

601

701

801

901

1001

1101

1201

1301

1401

1501

1601

1701

1801

1901

2001

2101

TACCTGAGCGCTCCCTTTGCTGTTCGCAAGTTGCACCTGCCGTCGCCAAAATGCCCACCGTCGACGCCATAAGCGACCTCCCCAACCGCTTCACCAACGA M P T V D A I S D L A N R F T N D CCTCGAGCTGTTTCGCCCCCGAGGACCGAGATTTTGAGATCGCCACTGAGCTCAATGAGATCCCCGACCCTCTATCCGCCTCGAAGGACCCCGAGGATCGTO L E L C R R E D R E F E I A T E L N E I A D A L S A S K D P K I V TCGGTCGACTTCCACCCAATGTACAACGCCGTCAACCACCACTGCGAGTTGTACGACCTGGTCGACCGCCCCACCGACTGCGTGGTCGTCCGTCGTGCGO S V D F P P M Y N A V N H H C E L Y E L V D R R T D C V V V R R G

GOCTCCTCTCCATGGTCGTCAAGCTGAACCAGAACGTOCCGCTCOCCTCCGCTCACGAGCTCAAGTTCTACTTCTCCTTCOGTTCTCCCCCTAACGTCGA G L L S M V V K L N Q N V A L A S A Q E L K F Y F S F G S R P N V E GAAGGCGACOCAGGCTCACCTCGTTGTCACGGGAAAAACCAAGATTGAAAAACCCCACGACGACTGGGACATAAGCCTCGTCAAGGAGGCGGGAAAGAAC

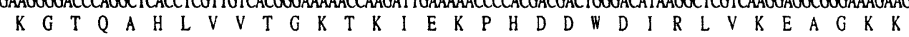

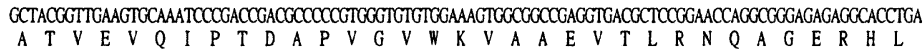

GGCGGTTCGACACGCACGTCTATATCCTCTTCAATCCCTGGATGAAAATGATGGCACATACCTTCCCGAGGAAAAAATGCGCCAGGAGTATGTGCTTTC R R F $F$ TGCCGTAGGCACGGTTTTCGTGGGCAGTTACCCOCACACTCGTGGCOCCCACTGGGCCTTCGGGCAGTTCGACGACGCCGTGCTGCCGCCATGCATOCTG A V G T V F V G S Y P H T R G R H W A F G Q F D D A V L P A C M L

CTGCTCGAGAGGTCGGGCGTCAGTGCCGAGGCCCGCGCGGACCOCGTCCGAATGTCGAGGCCCCTCTCCAAGATGGTGAACAGCAACGATGACTCCCGCC L L E R S G V S A E A R G D P V R M S R A L S K M V N S N D D S G

TTCTCGTCGGCAAGTGGGACGGAGAGTACGAGGACGCCAGGGCGCCCCOCAAGTCGCTCGGTTCGATCGAGATTCTOGAGATGTACCTCAGGACACCGCA L L V G K W D G E Y E D G R A P A K W L G S I E I L E M Y L R T R GTCGGTGAAGTACGGCCAGTGCTGGGTGTTCGCCGCCTGTCTCAACACCATATGTCCCGCCCTGCGTCTCCCGTGCCGIGTCGTGACCAACTTOGCCTCT $S$ V K Y GCACACGACACCAACATCTCACTCTCCATCGACGAATACTTTGACGAGGACGCCGACCAGATCGATCCAGCCGATCGTTACGTCAACCCAGCTCGCATTC A H D T N I S L S I D E Y F D E D G D Q I I D A A GTGACTCCATCTCGAACTTCCACGTTTGGATGACGIGTCGATGACCCGACCTGACCTCCCTGACGGTTTCGGACGCTCCCACGTCATCGACCCCACGCC ACAGGAGACGAGCGATCGGTOCTACCAGTGCGCOCCACCTTCCCACGAGGCCATCAGCCAGGGCOGCGTCGACCTGAAGTACGACGTCCOCTTOGTCCTO Q E T S D $D$ G S Y Q C G P A $S$ H GCCGAGGTCAACGCTGATGTCGTGCGCTGGCAGAaGGACGACCGGGCGGAGGGAGGATTCAAGAAGCTGGCGACGCAAACGAGCAGCGTGGGCCGCCTGA

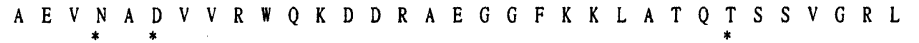
TCCTGACGAAGAAAGCCGGTCCCGTGGCCACAGGAGGGTTCTTCAAGTCCGACCCCCGAGGACATCACGTGCGAATACAAGCCCCCCGGGGGAACGCCGCGC I L T K K A G P V A T G G F F K S D R E D I T W E Y K P P CGAGAGGGTCAGCATCCTCAACCCCGCTCGAAGGACCOCCACCGCTCGCCAAGTCTTCGACATGCOCAGCGAGGCCAAGGAGGACGTGACTTTCCAGATC E R V S I L N A A R R T R T A R Q V F D M P S E A K E D V T T F GAGGACCGCGATCAGGTCCCCATCGGCGATAATTTCTCCGTCACGATAACCCCCACGAACACCAGCAGCGAGGTGAGGACGATCAACGTAGTGATGACCT E D R D Q V P P I G D N F S V T I T A T N T S S E V R T I N V V M T

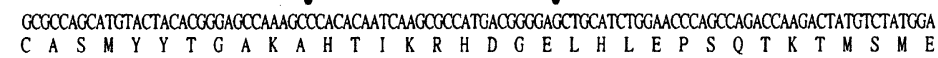
AGTCTACTATTCTGACTACTACTCGAAGCTTGTGGACCATGACCTTATCAAGAGCATTGTCATCTCCAACGTGAATGAAACGACOCAGTGCTGGGGCGGG $\begin{array}{lllllllllllllllllllllllllllllllll}V & Y & Y & S & D & Y & Y & S & K & L & V & D & H & D & L & I & K & S & \text { I } & V & I & C & N & V & N & E & T & T & Q & C & W & G & G\end{array}$ GAAGACAACCTGGAGGTTCACAAGCCTGATATCAACATTGAAGTGTTCGGATCGCCCGTGGAAGGTAAGCCTGTTCCTATCAACGTGTCCTTCGATAACC E D N L E V H K P D I N I E V L G S A V E G K A V P I K V S F D N CTATTCCACTGCTGTTGAAAGAATGCTGTCTGAAGCTGGACGGGCCGCGGCTCATGCGTCCGAAGACAGTGCCACTCGAAAACATCGCCCCCCAAAGGAAA P I P L L L K E C C L K L D G P G L M R P K T V P L E N I A P K G K

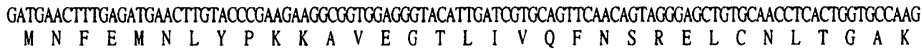
AAGATTAGCGTGGCCAGTGCTTGAATCTGGAGACGAACTGAGAAGCTTACAATTCTGGGTTTATTTATTTTGTTTTGCGTGGCCCGGCGACTAAAAAAAA K I S V A S A stop

AACTTAAGCCAAAGAGAGAACCCTTTTCCTGTTTGTTGTTTTACGCTTATGTGTAGCCCTATTTCCCTACTAACAATGTTGAGCATTAAGTTCCTTAGAT AAAAACTTATAGGATTTAAGAACAGTATTCTOCATACGTATTTACCAAGAGCTTTGGGAATAAGTATGTGAAATGCACTTAATGTATTTTTOCTTTATGT TTGAATTAGCTATAGGTAAGTTAATTAAAAAAAAATCCAATAGCTTAATTTTTGTTTAAGTAATATATTGAATAACCGTCAAATGCCCTGATCAACATAA GTCTGATAACAATATCTGAATTCAAAATGGTATTATAGTATCOCAGTAAACTATAGTATGATTAATACAAGACTAATATCAAACCTGGTTTATCATTGC GAAATTCCAGGAAATCACATAGAGAAATGTTTGTTAGAAGCAAATTAATATTTTOCTTTTTTATCATTTCTTTTTAATTCGAAGAGTAAGAAACATACCA AATTATGTTTAGTTTOCAACGATTGTATTGTTGATGTCAGCTGCTTCTTTAATAAATATGTACCAAAATCAAAAAAAAAAAAAAAAAA

Fig. 1. Nucleotide and deduced amino acid sequences of tiger shrimp TG. The number of nucleotides is shown in the right column of numbers; the number of amino acids is shown in the left column. The integrin-binding motif (RGD) and polyadenylation signal (ATTAAA) are underlined. The catalytic triad is shown with bold font and italics. Amino acid residues potentially involved with calcium binding are indicated with an asterisk ' $*$ '. Four putative glycosylation sites are indicated with dots. 


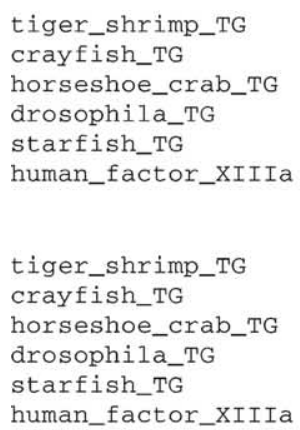

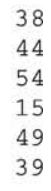

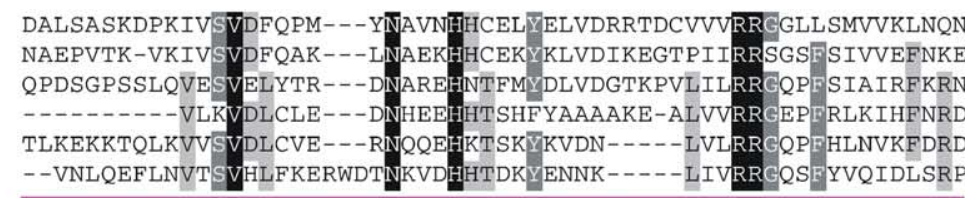

95 EIQVSSDAPVGVWSCSLEVRPKDETDASNRHLLR-LDTLLYILFNPWNENDSTYMAEEER 217 EIOI PAAVAVGVWKMKIVSQLTSEEQPNVSAVTHECKNKTYILFNPWCKQDSVYMEDEQW 228 LIKPPSTCPVTEWKLDIDTKLLGDGSRSYPLPLP-----IYVLFNPWCPDDQVYLEDRDQ 175 KVFCSSEALIGYYNLYILTMSGGD-EYEYESPKE-----LIMLFNAWCKDDDVYMADEVVK 209 SIQSSPKCIVGKFRMYVAVWTPYGVLRTSRNPET----DTYILFNPWCEDDAVYLDNEKE 201

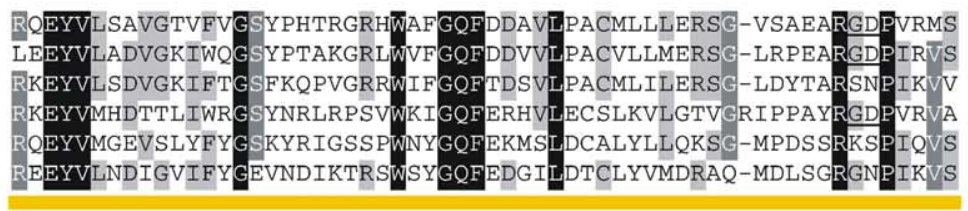

269 276 287

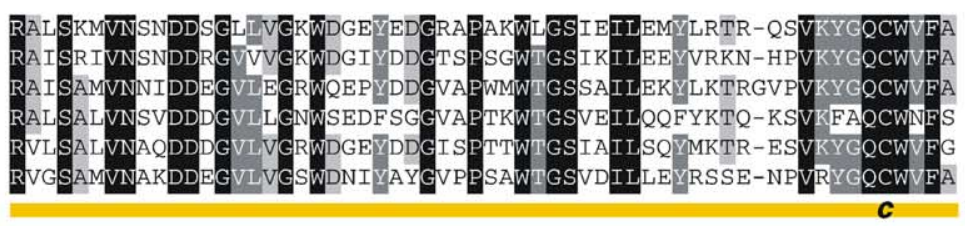

328

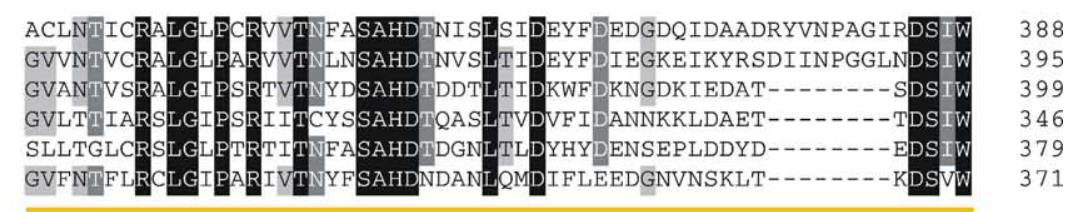

Fig. 2. Alignment of shrimp TG with crayfish TG (GenBank accession number: AAK69205), horseshoe crab TG (A45321), drosophila TG (AAF52590), starfish TG (BAB20439) and human factor XIIIa (NP_000120). Amino acid sequences start with the first methionine. Residues that are identical in all six sequences are enclosed in a black box (in web version). Residues identical in five sequences are enclosed in a dark gray box (in web version) and residues identical in four residues are enclosed in light gray (in web version). RGD motifs are underlined and amino acids in catalytic triads are shown in bold italics. Dots indicate amino acid residues that are probably involved with calcium binding. The identity and similarity of the residues of each species to shrimp TG are shown at the end of each TG sequence. The pink, orange, green, and blue bars (in web version) indicate the sandwich, core, barrel 1, and barrel 2, respectively. 

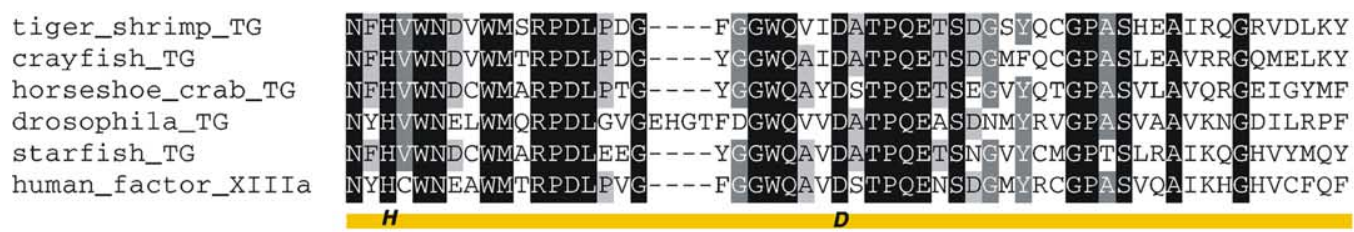

tiger_shrimp_TG crayfish_TG horseshoe_crab_TG drosophila_TG starfish_TG human_factor_XIIIa

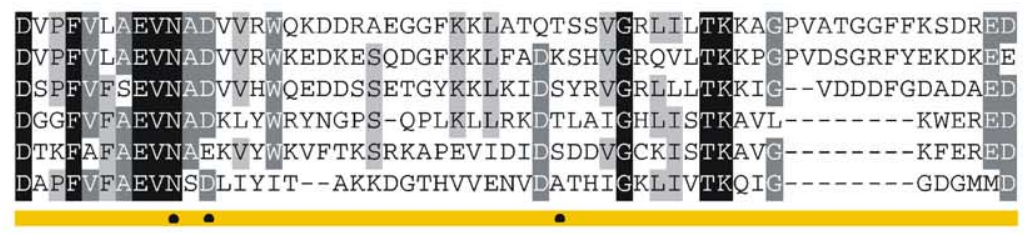

tiger_shrimp_TG crayfish_TG horseshoe_crab_TG drosophila_TG starfish_TG human_factor_XIIIa

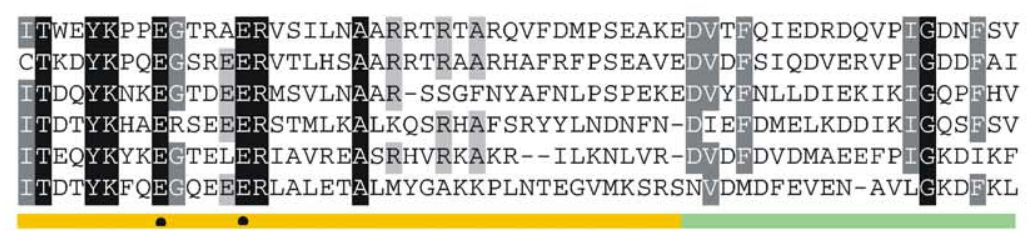

tiger_shrimp_TG crayfish_TG horseshoe_crab_TG drosophila_TG starfish_TG human_factor_XIIIa

tiger_shrimp_TG crayfish_TG horseshoe_crab_TG drosophila_TG starfish_TG human_factor_XIIIa

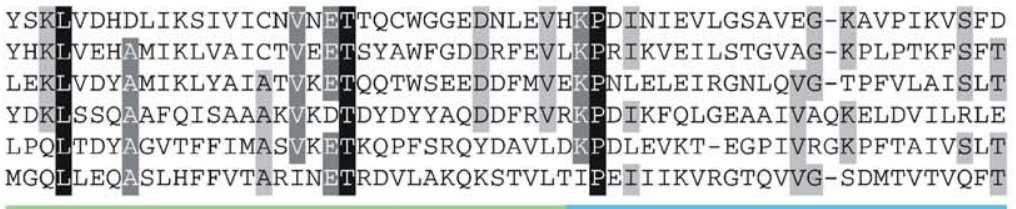

682 689 690 636 662 654

No

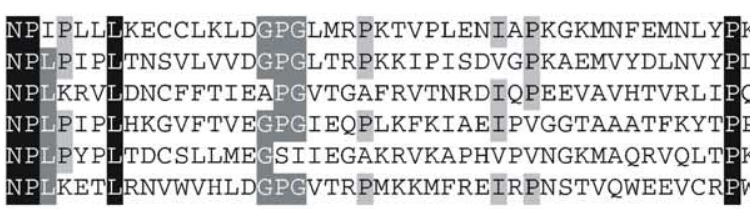

PKKAVEGTLIVQFNSRE
PLKEATCTLVASFNSTE
PQKPGPRKIVATF SSRQ
PPYAGRGTMLAKFT SKE
PKTAGSCDLIVSESSPQ
PWVSGHRKLIASMSSDS

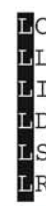

$\begin{array}{ccc}757 & \text { Identity } & \text { Similarity } \\ 766 & 55 \% & 71 \% \\ 764 & 43 \% & 59 \% \\ 736 & 34 \% & 52 \% \\ 737 & 36 \% & 53 \% \\ 732 & 34 \% & 44 \%\end{array}$

Fig. 2 (continued) 
Table 2

Similarity of shrimp TG protein domains to those of other species. Domain structure is based on X-ray crystallography of the structure of human factor XIIIa-subunit dimer $[43,46]$. The corresponding domains of other species were inferred from the sequence alignment shown in Fig. 2 Numbers $(\%)$ indicate sequence identity and similarity (in brackets)

\begin{tabular}{|c|c|c|c|c|}
\hline Origin of TG & Protein domains ${ }^{\mathrm{a}}$ & & & \\
\hline & $\beta$-Sandwich & Catalytic core & $\beta$-Barrel 1 & $\beta$-Barrel 2 \\
\hline Crayfish & $40(60)$ & $66(81)$ & $51(69)$ & $46(66)$ \\
\hline Horseshoe crab & $29(44)$ & $55(70)$ & $41(58)$ & $25(49)$ \\
\hline Starfish & $26(38)$ & $46(63)$ & $31(56)$ & $34(44)$ \\
\hline Drosophila & $22(32)$ & $43(60)$ & $30(48)$ & $28(49)$ \\
\hline Human factor XIIIa & $23(33)$ & $44(62)$ & $25(48)$ & $29(46)$ \\
\hline
\end{tabular}

a The four individual domains are shown in Fig. 2.

TG domains revealed that the highest identity/ similarity occurred between catalytic core domains, especially those of shrimp and crayfish (66/81\%) (Table 2). In the aligned TG, all amino acid residues involved in the catalytic triad are perfectly conserved (shrimp: Cys324, His391, Asp414; Fig. 2). The main human factor XIIIa $\mathrm{Ca}^{2+}$-binding site involves the main chain oxygen atom of Ala-457, and the side chains from residues Asn-436, Asp-438, Glu-485 and Glu-490 [39]. Except for Thr-477, the other four $\mathrm{Ca}^{2++}$-binding residues in shrimp TG (Asn454, Asp456, Glu513, Glu518) are conserved in all aligned proteins (Fig. 2). The sequence surrounding His352, Ser350-Ala-His-Asp353, was conserved. These data, along with crystallography data for factor XIIIa [40], suggest that His 352 interacts with Glu452. In contrast, residues for the putative GTP-binding region [41] in TG2 were not observed in shrimp TG.

To analyze the evolutionary relationship between shrimp TG and TG from other species, we calculated the amino acid similarity between aligned sequences. TG from different species are clearly related. All the algorithms indicated shrimp TG was most closely related to crayfish $\mathrm{TG}$, then horseshoe crab $\mathrm{TG}$, starfish TG, and insect TG. Among vertebrate TG, factor XIIIa and TG1 were most closely related to invertebrate TG (Fig. 3).

Shrimp TG contains the motif RGD (Arg-GlyAsp), which is present in most ligands binding to a family of membrane receptors called integrins [42]. An RGD motif is present in the same location in crayfish TG [23], fruit fly TG [30] and human keratinocyte TG $[43,44]$.

\subsection{Distribution of TG mRNA in shrimp tissues}

Based on RT-PCR analysis, low TG expression was detected in the intestine, hepatopancreas, gill, heart, lymphoid organ, sub-cuticular epithelium and hemocytes, but not the eyestalk (Fig. 4). In situ hybridization failed to detect signals in most tissues tested. However, strong TG signals were detected in young hemocytes in hematopoietic tissue (Fig. 5a). Binucleated cells and cells with more condensed cytoplasm always yielded stronger TG signals (Fig. 5b).

\subsection{Coagulation assay}

Only hemocyte lysate supernatant showed coagulation activity. No activity was detected in shrimp eyestalk, intestine, hepatopancreas, gill, heart, lymphoid organ or sub-cuticular epithelium cells. No coagulation activity was detected in Sf21 insect cells transfected with rTG or in untransfected Sf21 cells. TG from guinea pig liver exhibited no coagulation activity.

\section{Discussion}

We sequenced the full-length cDNA of a novel shrimp TG. By comparing shrimp TG to previously characterized TG, we found that the structural requirements for TG activity and $\mathrm{Ca}^{2+}$ binding are conserved. The TG catalytic mechanism was determined using biochemical data for several TG [2,3] 


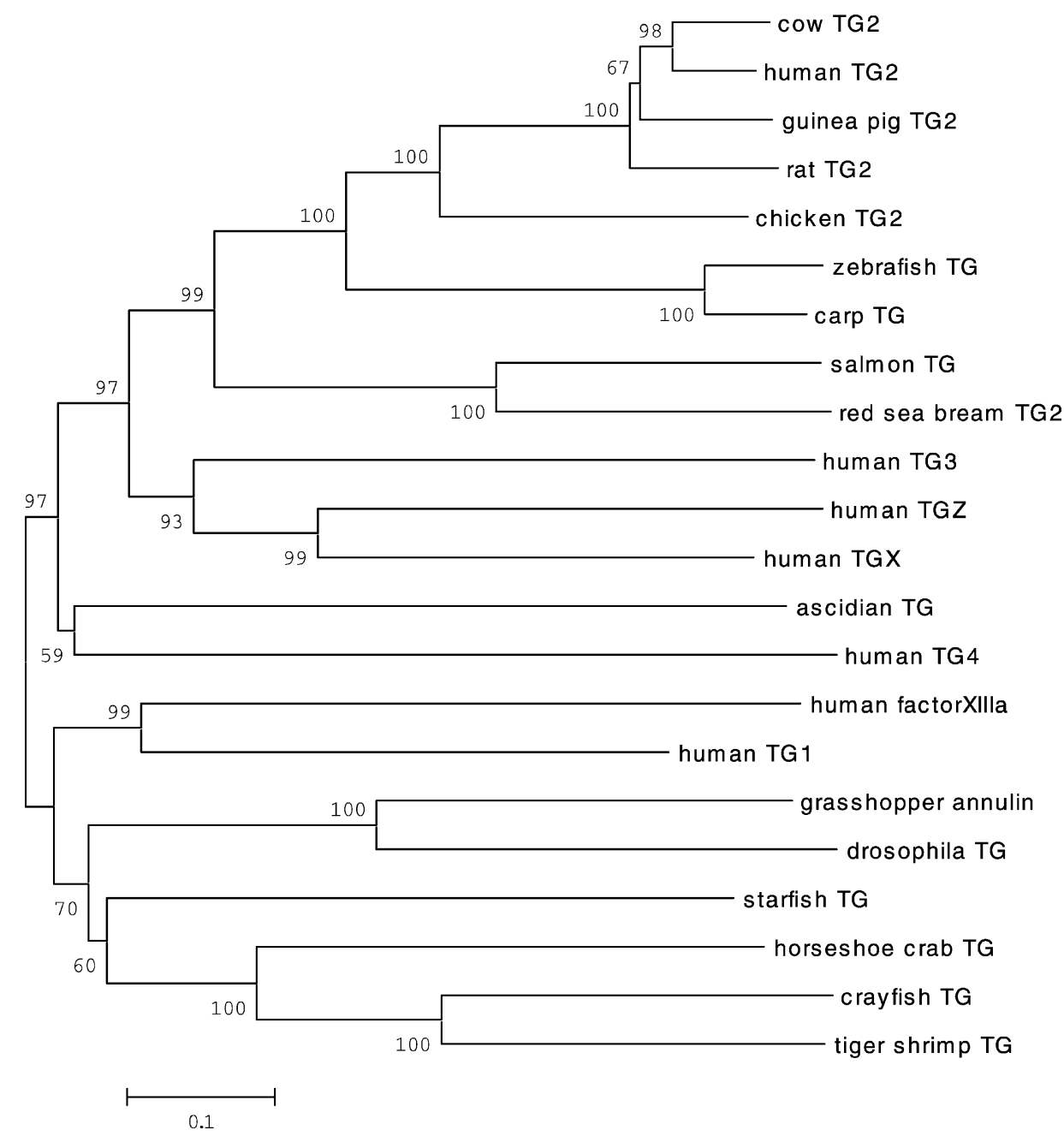

Fig. 3. Phylogenetic tree for shrimp TG and 23 other members of the TG family based on ClustalW alignment of amino acid sequences. Bootstrap values are given in percent and the scale bar indicates 0.1 substitution per site. The GenBank Accession numbers are: crayfish TG (AAK69205), horseshoe crab TG (A45321), starfish TG (BAB20439), drosophila TG (AAF52590), grasshopper annulin (P52183), human factor XIIIa (NP_000120), human TG1 (NP_000350), human TG4 (AAH07003), ascidian TG (CAA71263), human TG X (AAF23981), human TG Z (NP_443187), human TG3 (XP_009572), red sea bream TG (P52181), salmon TG (JC5133), carp TG (AAL02240), zebra fish TG (AAF61256), chicken TG2 (AAB58463), rat TG2 (NP_062259), guinea pig TG2 (P08587), human TG2 (XP_028806), cow TG2 (P51176).

and X-ray crystallography data on the structure of the factor XIIIa-subunit dimer [45]. The reaction center is formed by a core domain. In the active site, Cys forms hydrogen bonds to His and Asp residues to form a catalytic triad similar to the Cys-His-Asn triad found in the papain family of cysteine proteases [46]. The catalytic triad residues are conserved in shrimp TG. In addition, the core domain is highly conserved, exhibiting 43-66\% sequence identity with other
TG. Nearly every tryptophan in the catalytic core domain is conserved, including Trp289 in shrimp TG. The corresponding residue Trp241 in TG2 is highly conserved in the TG family and is critical for catalysis, possibly stabilizing the transition states. No enzyme activity was detected when Trp241 was replaced with Ala or Gln [47].

The transfer reaction catalyzed by TG depends on a conformational change induced by binding divalent 


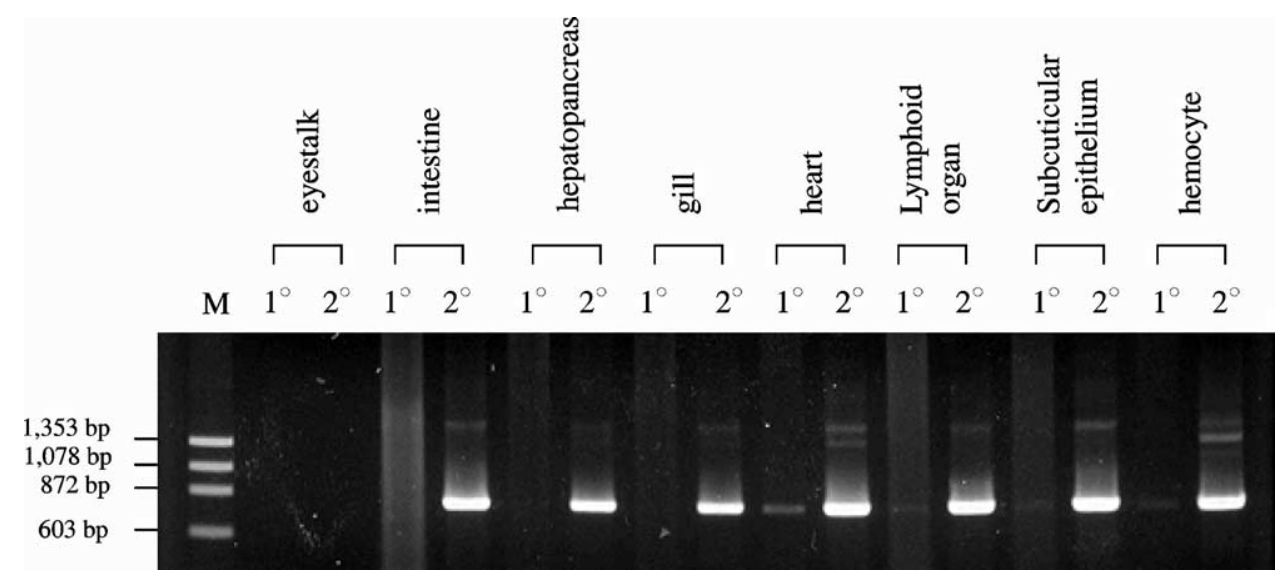

Fig. 4. RT-PCR analysis of TG expression. Total RNA was extracted from the eyestalk, intestine, hepatopancreas, gill, heart, lymphoid organ, subcuticular epithelium and hemocytes of Penaeus monodon. Primers specific for Penaeus monodon TG were designed to amplify an 806-bp fragment. RT was omitted from the control reaction to ensure that the amplified band is derived from RNA. The PCR bands were sequenced to ensure that they corresponded to the expected cDNA. M, marker; $1^{\circ}$, first round PCR; $2^{\circ}$, second round PCR.

cations, especially $\mathrm{Ca}^{2+}[1]$. Shrimp TG lacks a typical $\mathrm{Ca}^{2+}$-binding motif, such as the EF-hand structure that comprises the calcium binding site of calmodulin and many other proteins. The affinity of shrimp TG $\mathrm{Ca}^{2+}$-binding sites is low and excess EDTA easily blocked TG catalysis. The structure of these sites probably differs from that of high affinity sites in typical $\mathrm{Ca}^{2+}$-binding proteins. In TG, regions rich in negatively charged residues are potential $\mathrm{Ca}^{2+}$. binding sites [48]. Except Thr-477, all the amino acids thought to be involved in calcium binding are conserved in shrimp TG.

A typical hydrophobic leader sequence and a transmembrane domain could not be identified in the deduced sequence of shrimp TG. Thus, shrimp TG may be a typical cytoplasmic protein. Glycosylation of a protein lacking a leader sequence cannot occur because, during synthesis, the cytoplasmic protein would not be translocated into lumen of the endoplasmic reticulum (ER) and Golgi apparatus where glycosylation takes place. All characterized TG lack a hydrophobic leader sequence and none are known to undergo glycosylation $[1,5,10,22,26,28,29$, 43,44,49-51]. Expressing the factor XIIIa-subunit as a fusion protein with the preprodomain of a secretory protein in yeast yielded glycosylated variants of factor XIII that were largely retained and degraded in the ER [52]. Targeting the factor XIIIa-subunit to the conventional secretory pathway apparently causes aberrant, post-translational modifications. Although TG are not conventionally secreted proteins and the mechanism for the release of TG from cells remains unclear, the presence of TG in extracellular space is well documented. Factor XIII circulates in blood plasma, TG4 is a component of semen and TG2 is expressed on the surface of many cells, including fibroblasts, macrophages, hepatocytes and endothelial cells [53-56]. In invertebrates, blood clotting reduces blood and body fluid loss following injury. In crayfish, an endogenous TG is involved in the rapid assembly of a specific, plasma clotting protein [24]. The mechanism by which TG induces clotting of the clotting protein has been studied in detail in crayfish. Crayfish TG cross-links the clotting protein via its free glutamine and lysine residues. This TG-mediated polymerization occurs very rapidly [57]. In addition, crayfish TG can use alpha-2-macroglobulin as a substrate. However, if the alpha-2-macroglobulin thiolester region is destroyed by methylamine treatment, TG fails to recognize it as a substrate [58]. Recently, a shrimp (P. monodon) hemolymph clotting protein was characterized [59]. The specific role of shrimp TG in coagulation of the clotting protein has yet to be studied.

In this study, RT-PCR analysis of TG mRNA using TG-specific primers showed that expression is widespread, except in the eyestalk. However, the lack of a detectable band in the eyestalk does not mean TG 

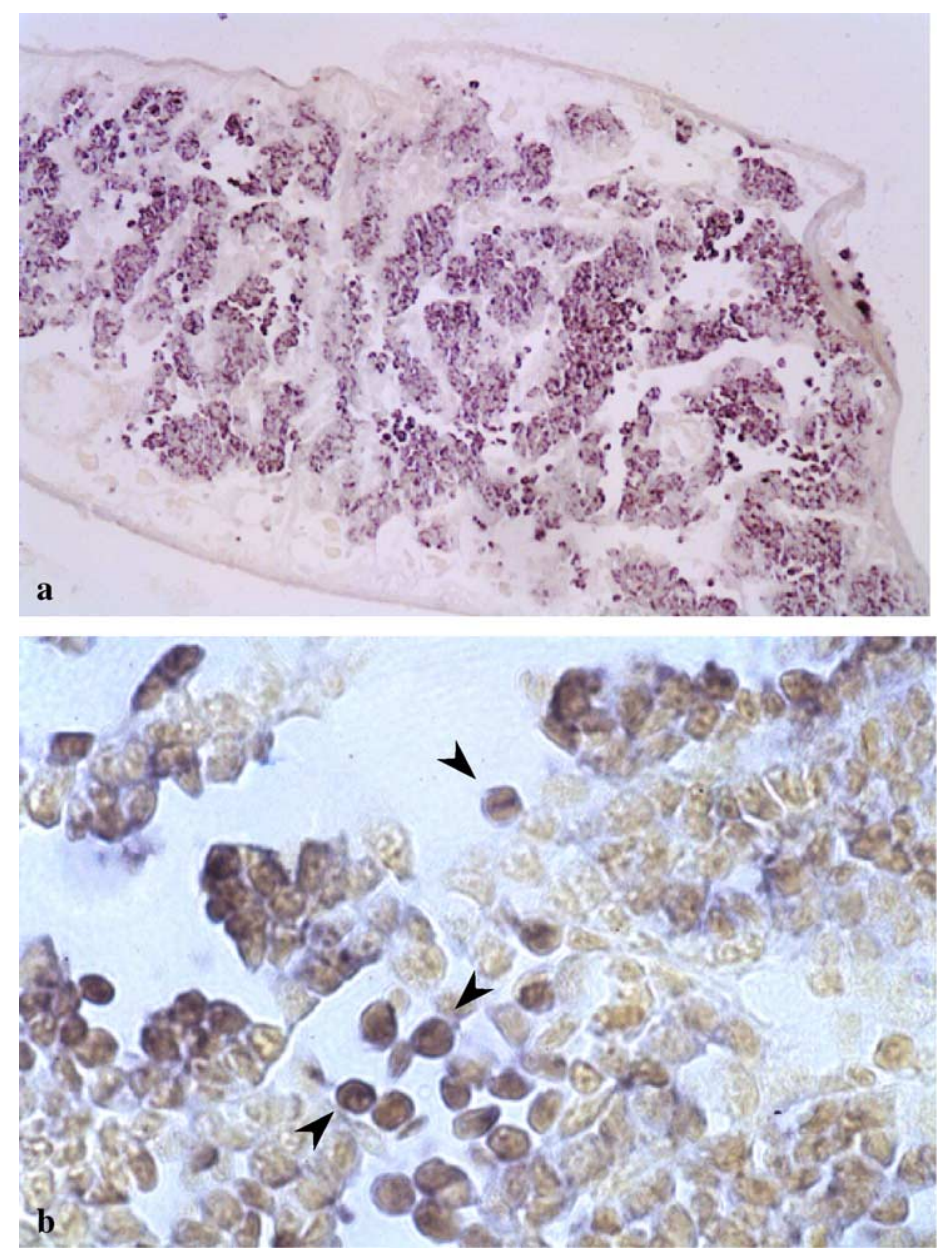

Fig. 5. In situ hybridization of shrimp TG mRNA in hematopoietic tissue. (a) In situ hybridization with an antisense shrimp TG riboprobe. The sections were slightly counterstained with Bismarck Brown Y. Positive signals were observed in hemocytes. No positive signals were observed when using a sense TG riboprobe (data not shown) $(\times 200)$. (b) Binucleated cells and cells with more condensed cytoplasm (arrow heads) always contained stronger signals for TG $(\times 1000)$.

mRNA was absent. PCR inhibitors are present in the eyestalk and always cause the amplification reaction to fail [60]. It usually took two rounds of PCR to visualize the amplified fragment, indicating TG gene expression was low in all organs tested or expression was restricted to a limited number of cells. In situ hybridization, failed to detect signals in these same organs, confirming that TG expression was very low. We could not determine the specific cell types that synthesize TG in these organs. Both RT-PCR and in situ hybridization indicated that the level of TG mRNA was very low in circulating hemocytes.
However, young hemocytes in hematopoietic tissue gave strong signals. Furthermore, binucleated cells and cells with more condensed cytoplasm, i.e. cells undergoing mitosis, yielded strong signals. This indicates cell proliferation and TG synthesis may be associated. Synthesis of shrimp TG may be associated with the cell cycle. Synthesis and storage of TG in young hemocytes facilitates the instant release of TG protein and blood clotting following injury. Enzyme activity was detected in all organs tested. TG activity was greatest in the hepatopancreas, then the heart, hemocytes and other organs (Table 1). However, only 
hemocyte lysate supernatant showed coagulation activity. No activity was detected in other tissues. These results imply that shrimp may contain more than one type of TG. It is very difficult to distinguish different types of TG with a TG activity assay. In tissues, TG activity was not directly correlated to mRNA level. Previous research has documented the expression pattern of TG by measuring mRNA and protein levels. TG2 transcript is most abundant in the lungs, then the heart, kidneys, red blood cells, liver, spleen, and testes $[6,61-63]$. However, TG2 protein is most abundant in the liver, then the spleen, heart, kidney and lung [64]. These results imply that TG expression may be regulated at the transcriptional and translational levels, or by the protein turnover rate. In vertebrates, the liver and blood cells are important sites for TG expression. For example, platelets, peripheral blood monocytes and the liver may be the primary sites for plasma factor XIII synthesis $[65,66]$. In shrimp, the hepatopancreas and hemocytes could also be important sites for TG expression. In crayfish and horseshoe crabs, the patterns of TG expression at the mRNA and protein levels are different $[23,25]$. Each invertebrate TG could correspond to a specific type of TG found in vertebrates. Further research is needed to clarify the function and regulation of invertebrate TG.

TG activity was detected in Sf21 cells transfected with rTG. However, the same cells showed no coagulation activity. It is possible that the shrimp TG isolated in this study is not involved in coagulation. Another possibility is that clot formation in shrimp involves cross-linking of plasma clotting protein with components in hemocytes. In horseshoe crabs, coagulin formed coagulin gel during the early stages of coagulation [67]. During the final stage, TG cross-linked proxins, a substrate of $\mathrm{TG}$, with coagulin to form a stable reticulate structure [27]. Coagulin lacks glutamine residues that function as amine acceptors, but it has several lysine residues that function as amine donors for protein cross-linking with proxins. Thus, TG does not cross-link coagulogen or coagulin, but it does cross-link proxins with coagulin [27]. Although TG acts solely on peptidebonded glutamine residues, the specificity of different TG for different substrates, such as glutaminyl, varies [2]. Moreover, a specific TG may recognize a protein as substrate, but will have a different affinity and specificity for different glutamine residues. For example, factor XIIIa has more stringent structural requirements for glutaminyl substrates than does TG2 $[68,69]$. Thus, different substrates and assay techniques may yield different results due to differences in sensitivity.

Based on amino acid similarity, vertebrate factor XIIIa and TG1 were the vertebrate TG most closely related to shrimp and other invertebrate TG. This is consistent with the finding that invertebrate TG is involved in blood clotting [24].

Based on the preservation of residues critical for enzyme function and domain folding, and the extensive, overall similarity of shrimp TG to the other members of the TG family with catalytic activity, we postulate that the cDNA characterized in this study encodes shrimp TG. Further research is needed to clarify the function and regulation of shrimp TG.

\section{Acknowledgements}

We thank Prof. Yu-Chan Chao, Institute of Molecular Biology, Academia Sinica, for kindly providing the baculovirus transfer vector $\mathrm{pABhRpX}$. This work is financially supported by grant (NSC922313-B-002-079) from the National Science Council, Republic of China and the Swedish Research Council.

\section{References}

[1] Folk JE, Finlayson JS. The $\varepsilon$-( $\beta$-glutamyl) lysine cross-link and the catalytic role of transglutaminase. Adv Protein** Chem 1977;31:1-133.

[2] Folk JF. Transglutaminase. Annu Rev Biochem 1980;49: 517-31.

[3] Lorand L, Conrad SM. Transglutaminases. Mol Cell Biochem 1984;58:9-35.

[4] Greenberg CS, Brickbichler PJ, Rice RH. Transglutaminases: multifunction cross-linking enzymes that stabilize tissue. FASEB J. 1991;5:3071-7.

[5] Grenard P, Bates MK, Aeschlimann D. Evolution of transglutaminase genes: identification of a transglutaminase gene cluster on human chromosome 15q15. J Biol Chem 2001; 276:33066-78.

[6] Aeschlimann D, Paulsson M. Transglutaminase: protein crosslinking enzymes in tissues and body fluid. Thromb Haemostasis 1994;71(4):402-15. 
[7] Kim SY, Chung S-I, Steinert PM. Highly active soluble processed forms of the transglutaminase 1 enzyme in epidermal keratinocytes. J Biol Chem 1995;270:18026-35.

[8] Esposito C, Pucci P, Amoresano A, Marino G, Cozzolino A, Porta P. Transglutaminase from rat coagulating gland secretion. J Biol Chem 1996;271:27416-23.

[9] Steinert PM, Kim S-Y, Chung S-I, Marekov LN. The transglutaminase 1 enzyme is variably acylated by myristate and palmitate during differentiation in epidermal keratinocytes. J Biol Chem 1996;271:26242-50.

[10] Aeschlimann D, Koeller MK, Alen-Hoffmann BL, Mosher DF. Isolation of a cDNA encoding a novel member of the transglutaminase gene family from human keratinocytes. J Biol Chem 1998;273:3452-60.

[11] Ichinose A, Bottenus RE, Davie EW. Structure of transglutaminase. J Biol Chem 1990;265:13411-4.

[12] Martinet N, Kim HC, Girard JE, Nigra TP, Strong DH, Chung S-I, Folk JE. Epidermal and hair follicle transglutaminase. Partial characterization of soluble enzymes in newborn mouse skins. J Biol Chem 1988;263:4236-41.

[13] Rice RH, Rong X, Chakravarty R. Proteolytic release of keratinocyte transglutaminase. Biochem J 1990;265:351-7.

[14] Candi E, Melino G, Mei G, Tarcsa E, Chung SI, Marekov LN, Steinert PM. Biochemical, structural, and transglutaminase substrate properties of human lorcrin, the major epidermal cornified cell envelope protein. J Biol Chem 1995;270: 26382-90.

[15] Tarcas E, Marekov LN, Andreoli J, Isler WW, Candi E, Chung SI, Steinert PM. The fate of trichohyalin. Sequential posttranslational modifications by peptidyl-arginine deiminase and transglutaminases. J Biol Chem 1997;272:27893-901.

[16] Steinert PM, Kartasova T, Marekov LN. Biochemical evidence that small proline-rich proteins and trichohyalin function in epithelia by modulation of the biochemical properties of their cornified cell envelopes. J Biol Chem 1998;273:11758-69.

[17] Achyuthan KE, Greenberg CS. Identification of a guanosine triphosphate-binding site on guinea pig liver. J Biol Chem 1987;262:1901-6.

[18] Kojima S, Inui T, Muramatsu H, Suzuki Y, Kadomatsu K, Yoshizawa M, Hirose S, Sakakibara S, Muramatsu T. Dimerization of midkine by tissue transglutaminase and its functional implication. J Biol Chem 1997;272:9410-6.

[19] Nunes I, Gleizes PE, Metz CN, Rifkin DB. Latent transforming growth factor-beta binding protein domains involved in activation and transglutaminase-dependent cross-linking of latent transforming growth factor-beta. J Cell Biol 1997;136:1151-63.

[20] Melino G, Piacentini M. Tissue transglutaminase in cell death: a downstream or a multifunctional upstream effector? FEBS Lett 1998;430:59-63.

[21] Aeschlimann D, Thomazy V. Protein crosslinking in assembly and remodeling of extracellular matrixes: the role of transglutaminases. Connect Tissue Res 2000;41:1-27.

[22] Ho KC, Quarmby VE, French FS, Wilson EM. Molecular cloning of rat prostate transglutaminase complementary DNA. The major androgen-regulated protein DP1 of rat dorsal prostate and coagulating gland. J Biol Chem 1992;267: 12660-7.

[23] Wang R, Liang Z, Hall M, Soderhall K. A transglutaminase involved in the coagulation system of the freshwater crayfish. Pacifastacus leniusculus. Tissue localization and cDNA cloning. Fish Shellfish Immunol 2001;11:623-37.

[24] Hall M, Wang R, Antwerpen RV, Sottrup-Jensen L, Soderhall $\mathrm{K}$. The crayfish plasma clotting protein: a vitellogenin-related protein responsible for clot formation in crustacean blood. Proc Natl Acad Sci 1997;96:1965-70.

[25] Tokunaga F, Yamada M, Miyata T, Ding Y-L, HiranagaKawabata M, Muta T, Iwanaga S, Ichinose A, Davie EW. Limulus hemocyte transglutaminase. Its purification and characterization, and identification of the intracellular substrates. J Biol Chem 1993;268:252-61.

[26] Tokunaga F, Muta T, Iwanaga S, Ichinose A, Davie EW, Kuma K, Miyata T. Limulus hemocyte transglutaminase CDNA cloning, amino acid sequence, and tissue localization. J Biol Chem 1993;268:262-8.

[27] Osaki T, Okino N, Tokunaga F, Iwanaga S, Kawabata S. Proline-rich cell surface antigens of horseshoe crab hemocytes are substrates for protein cross-linking with a clotting protein coagulin. J Biol Chem 2002;277:40084-90.

[28] Singer MA, Hortsch M, Goodman CS, Bentley D. Annulin, a protein expressed at limb segment boundaries in the grasshopper embryo, is homologous to protein cross-linking transglutaminase. Dev Biol 1992;154:143-59.

[29] Sugino H, Terakawa Y, Yamasaki A, Nakamura K, Higuchi Y, Matsubara J, Kuniyoshi H, Ikegami S. Molecular characterization of a novel nuclear transglutaminase that is expressed during starfish embryogenesis. Eur J Biochem 2002;269: 1957-67.

[30] Adams MD, Celniker SE, et al. The genome sequence of Drosophila melanogaster. Science 2000;287:2185-95.

[31] Vargas-Albores F, Guzman-Murillo MA, Ochoa JL. An anticoagulant solution for haemolymph collection and prophenoloxidase studies of penaeid shrimp (Penaeus californiensis). Comp Biochem Physiol 1993;106A:299-303.

[32] Hasson KW, Hasson J, Aubert H, Redman RM, Lightner DV. A new RNA-friendly fixative for the preservation of penaeid shrimp samples for virological detection using cDNA genomic probes. J Virol Meth 1997;66:227-36.

[33] Song YL, Yu CI, Lien TW, Huang CC, Lin MN. Haemolymph parameters of Pacific white shrimp (Litopenaeus vannamei) infected with Taura syndrome virus. Fish shellfish Immunol 2003; $14: 317-331$

[34] Bradford MM. A rapid and sensitive method for the quantitation of microgram quantities of proteins utilizing the principle of protein-dye binding. Anal Biochem 1976;72:248-54.

[35] Xia X, Xie Z. DAMBE: Data analysis in molecular biology and evolution. J Hered 2001;92:371-3.

[36] Kumar S, Tamura K, Jakobsen IB, Nei M. MEGA2: molecular evolutionary genetics analysis software. Bioinformatics 2001; 17:1244-5.

[37] Saitou N, Nei M. The neighbor-joining method: a new method for reconstructing phylogenetic trees. Mol Biol Evol 1987;4: $406-25$. 
[38] Kozak M. Point mutations define a sequence flanking the AUG initiation codon that modulates translation by eukaryotic ribosomes. Cell 1986;44:283-92.

[39] Fox BA, Yee VC, Pedersen LC, Le Trong I, Bishop PD, Stenkamp RE, Teller DC. Identification of the calcium binding site and a novel ytterbium site in blood coagulation factor XIII by X-ray crystallography. J Biol Chem 1999;274: 4917-23.

[40] Iismaa SE, Chung L, Wu MJ, Teller DC, Yee VC, Graham RM. The core domain of the tissue transglutaminase Gh hydrolyzes GTP and ATP. Biochemistry 1997;36: 11655-64.

[41] Iismaa SE, Wu MJ, Nanda N, Church WB, Graham RM. GTP binding and signaling by $\mathrm{Gh} /$ transglutaminase II involves distinct residues in a unique GTP-binding pocket. J Biol Chem 2000;275:18259-65.

[42] Ruoslahti E. RGD and other recognition sequences for integrins. Annu Rev Cell Dev Biol 1996;12:697-715.

[43] Phillips MA, Stewart BE, Qin Q, Chakravarty R, Floyd EE, Jetten AM, Rice RH. Primary structure of keratinocyte transglutaminase. Proc Natl Acad Sci 1990;87:9333-7.

[44] Kim HC, Idler WW, Kim IG, Han JH, Chung SI, Steinert PM. The complete amino acid sequence of the human translutaminase K enzyme deduced from the nucleic acid sequences of cDNA clones. J Biol Chem 1991;266:536-9.

[45] Yee VC, Pedersen LC, Le Trong I, Bishop PD, Stenkamp RE, Teller DC. Three-dimensional structure of a transglutaminase: human blood coagulation factor XIIIa. Proc Natl Acad Sci 1994;91:7296-300.

[46] Pedersen LC, Yee VC, Bishop PD, LeTrong I, Teller RC, Stenkamp RE. Transglutaminase factor XIII uses protemaselike catalytic triad to crosslink macromolecules. Protein Sci 1994;3:1131-5.

[47] Prasanna Murthy SN, Iismaa S, Begg G, Freymann DM, Graham RM, Lorand L. Conserved tryptophan in the core domain of transglutaminase is essential for catalytic activity. Proc Natl Acad Sci 2002;99:2738-42.

[48] Yee VC, Le Trong I, Bishop PD, Pedersen LC, Stenkamp RE, Teller DC. Structure and function studies of factor XIIIa by X-ray crystallography. Semin Thromb Hemost 1996;22: 377-84.

[49] Grundmann U, Amann E, Zettlmeissl G, Kupper HA. Characterization of cDNA coding for human factor XIIIa. Proc Natl Acad Sci 1986;83:8024-8.

[50] Ichinose A, Hendrickson LE, Fujikawa K, Davie EW. Amino acid sequence of the a-subunit of human factor XIII. Biochemistry 1986;25:6900-6.

[51] Takahashi N, Takahashi Y, Putnam FW. Primary structure of blood coagulation factor XIIIa (fibrinoligase, transglutaminase) from human placenta. Proc Natl Acad Sci 1986;83: 8019-23.

[52] Tharaud C, Ribet A-M, Costes C, Gaillardin C. Secretion of human blood coagulation factor XIIIa by the yeast Yarrowia lipolytica. Gene 1994;121:111-9.

[53] Aeschlimann D, Koeller M, Paulsson M. Transglutaminasecatalyzed matrix crosslinking in differentiating cartilage:
Identification of osteonectin as a major glutaminyl substrate. J Cell Biol 1995;129:881-92.

[54] Barsigian C, Stern AM, Martinez J. Tissue (type II) transglutaminase covalently incorporates itself, fibrinogen, or fibronectin into high molecular weight complexes on the extracellular surface of isolated hepatocytes. J Biol Chem 1991;266:22501-9.

[55] Martinez J, Chalupowiez DG, Roush RK, Sheth A. Barsigian. Transglutaminase-mediated processing of fibronectin by endothelial cell monolayers. Biochemistry 1994; 33:2538-45.

[56] Verderio E, Nicholas B, Gross S, Griffin M. Regulated expression of tissue transglutaminase in Swiss $3 \mathrm{~T} 3$ fibroblasts: Effect on the processing of fibronectin, cell attachment, and cell death. Exp Cell Res 1998;239:119-38.

[57] Kopacek P, Hall M, Söderhäll K. Characterisation of a clotting protein isolated from the plasma of the freshwater crayfish Pacifastcaus leniusculus. Eur J Biochem 1993;213: 591-7.

[58] Hall M, Söderhäll K. Crayfish alpha-2-macroglobulin as a substrate for transglutaminases. Comp Biochem Physiol 1994; 108B:65-72.

[59] Yeh M-S, Huang C-J, Leu J-H, Lee Y-C, Tsai I-H. Molecular cloning and characterization of a hemolymph clottable protein from tiger shrimp (Penaeus monodon). Eur J Biochem 1999; 266:624-33.

[60] Lo CF, Ho CH, Chen CH, Liu KF, Chiu YL, Yeh PY, Prng SE, Hsu HC, Liu HC, Chang CF, Su MS, Wang CH, Kou GH. Detection and tissue tropism of white spot syndrome baculovirus (WSBV) in captured brooders of Penaeus monodon with a special emphasis on reproductive organs. Dis Aquat Org 1997;30:53-72.

[61] Gentile V, Saydak M, Chiocca EA, Akande O, Birckbichler PJ, Lee KN, Stein JP, Davies PJA. Isolation and charaterization of cDNA clones to mouse macrophage and human endothelial cell tissue transglutaminase. J Biol Chem 1991; 266:478-83.

[62] Nakanishi K, Nara K, Hagiwara H, Aoyama Y, Ueno H, Hirose S. Cloning and sequence analysis of cDNA clones for bovine aortic-endothelial-cell transglutaminase. Eur J Biochem 1991;202:15-21.

[63] Weraarchakul-Boonmark N, Jeong JM, Murthy SNP, Engel JD, Lorand L. Cloning and expression of chicken erythrocyte transglutaminase. Proc Natl Acad Sci 1992;89: 9804-8.

[64] Clarke DD, Mycek MJ, Neidle A, Waelsch H. The incorporation of amines into protein. Arch Biochem Biophys 1959;79:338-54.

[65] Weisberg LJ, Shiu DT, Conkling PR, Shuman MA. Identification of normal human peripheral blood monocytes and liver as sites of synthesis of coagulation factor XIII a-chain. Blood 1987;70:579-82.

[66] Poon M-C, Russell JA, Low S, Sinclair GD, Jones AR, Blahey W, Ruether BA, Hoar DI. Hemopoietic origin of factor XIII a-subunits in platelets, monocytes and plasma. Evidence from bone marrow transplantation studies. J Clin Invest 1989;84: $787-92$. 
[67] Kawasaki H, Nose T, Muta T, Iwanaga S, Shimohigashi Y, Kawabata S-I. Head-to-tail polymerization of coagulin, a clottable protein of the horseshoe crab. J Biol Chem 2000;275: 35297-301.

[68] Gorman JJ, Folk JE. Structure features of glutamine substrates for transglutaminase: Specificities of human plasma factor
XIIIa and the guinea pig liver enzyme toward synthetic peptides. J Biol Chem 1981;256:2712-5.

[69] Gorman JJ, Folk JE. Structural features of glutamine substrates for transglutaminase: role of extended interactions in the specificity of human plasma factor XIIIa and the guinea pig liver enzyme. J Biol Chem 1984;259:9007-10. 